\title{
COMPARISON OF TRY-ON OVER ACTUAL AND VIRTUAL MANNEQUINS FOR KNITWEAR GARMENTS
}

\author{
Arzu BOR KOCAMAN \\ Selcuk University, Turkey \\ arzubor@selcuk.edu.tr \\ https://orcid.org/0000-0002-7668-5624 \\ Nurgül KILINÇ \\ Selcuk University, Turkey \\ nkilinc@selcuk.edu.tr
}

\begin{abstract}
In this study, the aim is to evaluate the compatibility between the virtual try-on result with the actual try-on result by comparing the try-ons of a garment produced from knitwear fabric in actual and virtual environments. The patterns of the garment to be produced in accordance with this aim, were prepared by the researchers and after sewing prototype product with knitwear, the try-on was made on the real mannequin who has been taken measure body sizes on. Afterwards, the prepared patterns were transferred to the computer environment by digitizing in the Gerber Accumark program and the virtual trying-on was performed on the mannequin which created in V-Stitcher which is a 3-dimensional virtual simulation program. For the accordance between the virtual try-on and the actual try-on, a virtual mannequin has been created with the standards of the person who used for the body measurements. In addition, the knitwear fabric used in prototype production has been defined in the system by performing tests such as bending, stretch and shear parameters for carring the same characteristics with actual try-on. The compatibility of the virtual rehearsal and the actual rehearsal was assessed based on expert opinions. As a result of the research, it was determined that the results of the virtual rehearsals of the clothes produced from the knitwear are compatible with the actual rehearsal results.
\end{abstract}

Keywords: Knitwear, Virtual Try-On, V-Stitcher

\section{TRIKO GIYYSININ GERÇEK VE SANAL ORTAMLARDA YAPILAN PROVALARININ KARŞILAŞTIRILMASI}

\section{ÖZ}

$\mathrm{Bu}$ çalışmada, triko kumaştan üretilen bir giysinin gerçek provası ile sanal ortamda yapılan provasının karşılaştırılarak sanal prova sonuçlarının gerçek prova sonuçları ile uyumluluğunun değerlendirilmesi amaçlanmıştır. $\mathrm{Bu}$ amaç doğrultusunda tasarlanan giysinin kalıpları araştırmacılar tarafından hazırlanmış ve triko kumaştan prototip ürün dikilerek ölçüleri alınan kişi üzerinde gerçek provası yapılmıştır. Sonrasında hazırlanmış kalıplar Gerber Accumark programında dijit edilerek bilgisayar ortamına aktarılmış ve 3 boyutlu prova programı olan $\quad$ V-Stitcher'da oluşturulan manken üzerine giydirilerek sanal provası gerçekleştirilmiş̧ir. Sanal provanın gerçeğiyle uyumlu olması amacıyla prototip hazırlarken esas alınan kişinin ölçülerine uygun sanal manken oluşturulmuştur. Ayrıca, prototip üretiminde kullanılan kumaşlar aynı özellikleri yansıtması için bükülme, streç ve esneme testleri yapılarak sisteme tanımlanmıştır. Sanal prova ve gerçek provanın birbiri ile uyumluluğu uzman görüşlerine dayalı olarak değerlendirilmiştir. Araştırma sonucunda, triko kumaşlardan üretilen giysilerin sanal prova sonuçlarının gerçek prova sonuçları ile uyumlu olduğu tespit edilmiştir.

Anahtar Kelimeler: Triko Kumaş, Sanal Prova, Gerçek Prova, V-Stitcher 


\section{INTRODUCTION}

Textiles and apparel are leading sectors for many countries due to their high share in export revenues and added value created in the production process. A good structuring in this sector today requires successful implementation of various strategies. Among the strategies implemented, customer-focused mass production and mass customization have become almost imperative in order to find market share in the global competitive environment and to respond to ever-changing consumer demands. In customer-focused production, customers expect the necessary changes in each order to be achievable with minimal cost and in a short time (Ahlström and Westbrook, 1999: 264). The most important parameter affecting consumer satisfaction and purchasing decision in this direction is the fitting of the body in the clothes (Vuruşkan and Bulgun, 2013: 42).

There are no objective criteria and standard methods to evaluate the fit of the apparel to the body. But nowadays, innovations presented by the technology are used to evaluate the harmony of the clothes with the 3D clothing simulation programs (Iqbal, 2013: 25). These programs come with Lectra Modaris, V-StitcherTM-Browzwear, SimulatorTM TukaTech, Assyst Vidya and OptiTexTM 3D Runaway Designer. Designed with 3 dimensional garment simulation programs, garments are presented with an easy and error-free garment simulation technique (Tama et al., 2016: 170). Thanks to these programs, products are presented in a fast way, customer satisfaction is developing, more information is obtained about the target customers and the clothes designed for the customer's body are produced (Istook, 2008: 94). As a result, it can be said that online consumption has been opened, thus facilitating the purchasing behavior by giving the customer advantages from time and cost.

There are many studies on body adaptation, customer-focused production, and mass production, mass customization and 3 dimensional garment simulation programs. The contents of some of these studies are summarized below:

Fan, Yu and Hunter (2004), in their work on body fit and mass production; they have drawn attention to the preparation of mannequins for the target market, to carry out body suitability analyzes of clothes, to prepare molds for mass production, to take body measurements for body surveys. Yeşilpınar and Bulgun (2007), Turkish women aged 25-55 were most likely to encounter adaptation problems in which types of clothing and in which parts of clothing. As a result of the research, it was determined that only $9.2 \%$ of them did not have any adaptation problems in the clothes they bought. Bye and McKinney (2010), in addition to the factors such as customer satisfaction, the functionality of the garment, the concept of "good fit in garments" has been examined in order to evaluate the success of the manufacturers. Vurusskan and Bulgun (2013), in this study, taking the most common female body shapes as an example, body fit assessment was made between $\mathrm{m}-\mathrm{t}-\mathrm{m}$ and standard body clothes. As a result, m-t-m pants were found to fit better. Gürsoy, Doğan and K1lınç (2016), in this study, the aim is to evaluate the compatibility between the virtual try-on results with the actual try-on result by comparing the try-ons of a garment produced from Rize fabric in actual and virtual environments. It is observed that the try-on of the dress produced from Rize fabric, made in virtual and actual environment is very compatible with each other. Tama and others (2016), instead of preparing timeconsuming prototypes to determine the garment pattern, which is the best fit of the garment to the body, he has worked on the usability of 3 dimensional garment simulation programs.

It is important to be productive in terms of time, cost and labor with the use of 3 dimensional garment simulation programs, and to affect customer satisfaction and purchasing decision positively and thus serve customer-oriented marketing. In this study comparing the appearance of a garment produced with knitted fabric with the mentioned program, the measured bending, shear and stretching parameters of the knitted fabric were transferred to the computer and modeled. The measured bending, stretch and shear parameters of the knitted fabric has been transferred to the virtual environment and its modeling has been made with this study. In the study, it was aimed to evaluate the compatibility of the virtual rehearsal results with the actual rehearsal results by comparing the actual rehearsal of a garment made of knitwear with the rehearsal made in the virtual environment. In accordance with the general aim, the below questions are tried to be answered; 
1-In evaluating the body from front, rear and sidewise, how is the compatibility between the virtual try-on results with the actual try-on result?

2- In evaluating the arm, how is the compatibility between the virtual try-on results with the actual tryon result?

\section{METODOLOGY}

In this work, the upper body is made of knit fabric by removing the blouse pattern from the clothes variety. The blouse was designed as crew neck with ruffle, garment size finished under the hip line, long sleeve, arm and a skirt with a flywheel on the end. This blouse model was prepared so that the criteria such as the position of the ruffle and the flywheels can be examined. The compatibility in terms of the determined criteria of the virtual take-on and the actual take-on, was evaluated by basing on the expert opinions.

Before the cloth test of the garment, the fabric sample was not ironed. The virtual rehearsal was done with the V-StitcherTM-Browzwear program, which is a 3D virtual dressing simulations. The properties of the knitwear fabric (weight, bending, stretching and shearing properties of the fabric) were transferred to the virtual center after a number of tests were performed (Picture 1-2).

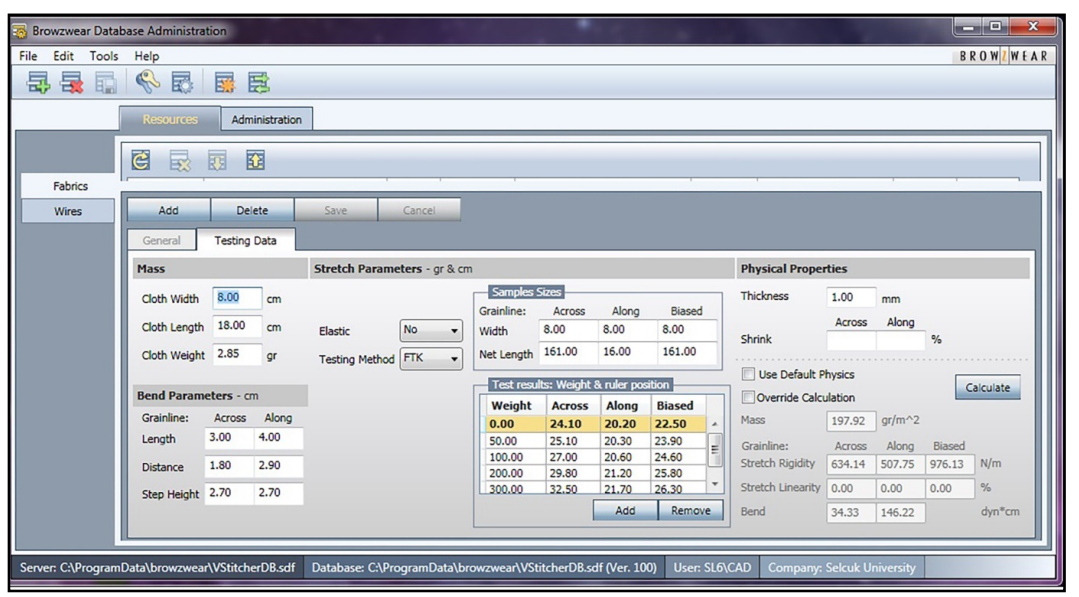

Picture 1. Identifying The Fabric Specifications to The System (Flat Knitting)

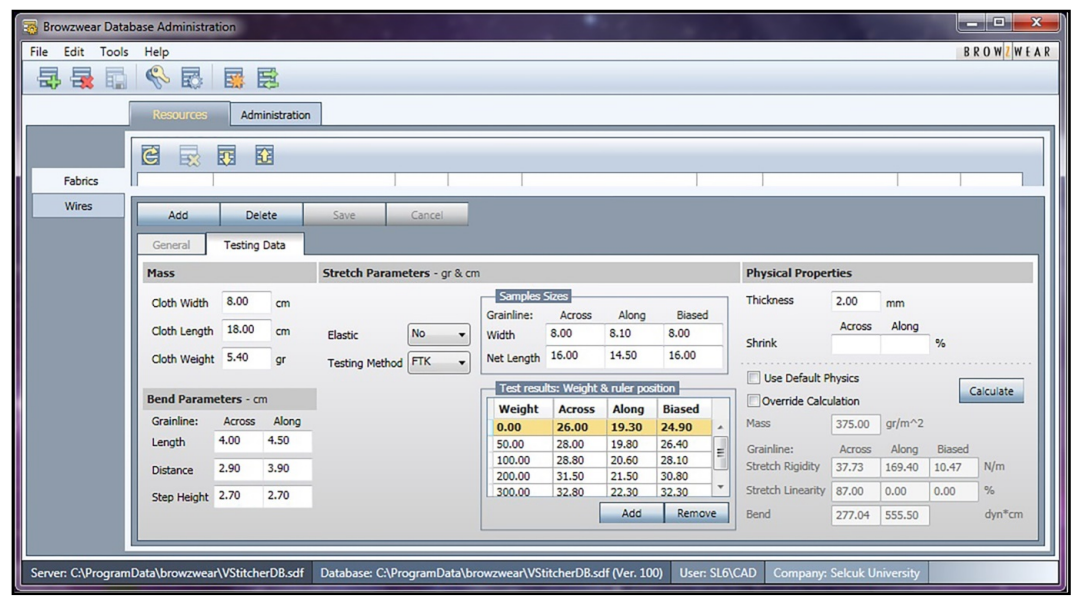

Picture 2. Identifying The Fabric Specifications to The System (Ribbed Knitted Fabric)

Fabric test kit was used for fabric made tests (Picture 3). All of the tests were repeated 3 times when the stretching, bending and shearing properties were detected. The arithmetic averages of the measurements were taken and the data were recorded on the computer. The samples used in the tests are knitted fabrics cut in width, size and dimensions of $8 \times 18 \mathrm{~cm}$ with 45 degree angle (Picture 4).

Submit Date: 14.03.2019, Acceptance Date: 12.05.2019, DOI NO: 10.7456/10903100/003 
In the bending test, the samples prepared from the width and length fabric are laid on the main scale and placed on the bending scale. The bending test bar is placed to the part of the fabric on the main scale and the fabric is pulled till the lower edge comes to the tangent form on the bending scale. In the final point where the fabric contacts with the bending scale ruler in tangent form, two measurements are made. The first measurement is the flat bend on the bending scale of the fabric (Distance). The second measurement is the measure of the hanging part of the fabric (Length) (Picture 5). In the stretch and slip test, 3 knit ties which are cut in width, length and width are measured 3 times as in the bending test. The fabric samples are affixed by being centered between the clips respectively and are placed to the test region. During the test, 0 gr (empty form), 50 gr, $100 \mathrm{gr}, 200 \mathrm{gr}$ and 300 gr weights are used and the value of the fabric sample on the rule is noted. The obtained results forms the stretch test results for longitudinal and transverse fabric sample and forms the shear test results of the bias fabric sample (Picture 6) (Browzwear kullanım klavuzu, 2010).

The obtained test date is recorded to parameter table in picture 1-2 and the bending, stretch and shear test values are calculated for the accurate identification of the knit fabric on the software.

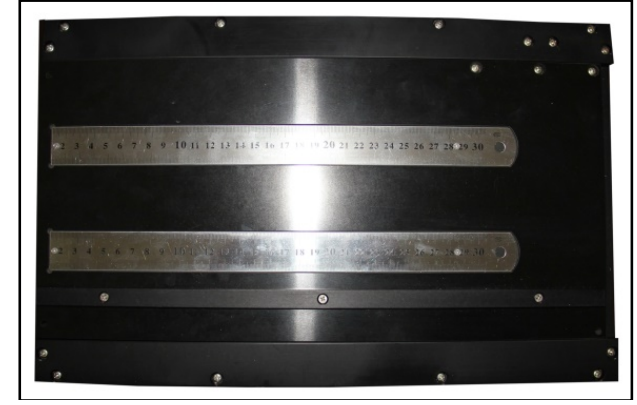

Picture 3. Fabric Test Kit

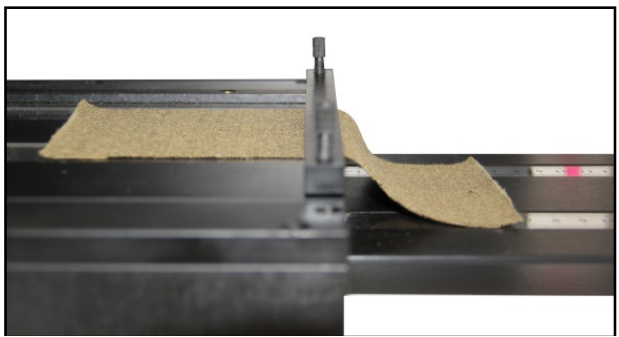

Picture 5. Bending Test

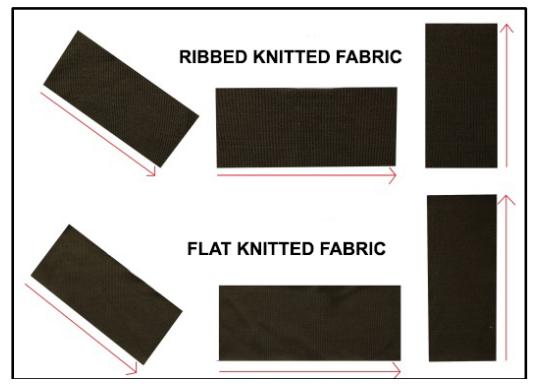

Picture 4. Width, Length and Slanting of The Knit.

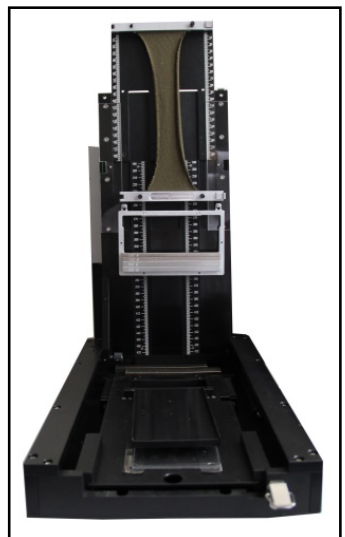

Picture 6. Stretch and Shear Tests

The virtual mannequin is created by entering the sizes of the living model to the system after the identification of the fabric. The body postures of the living model are reflected on the virtual mannequin. The patterns of the blouse to be produced which are prepared by the researchers, are transferred to the computer by making in digit form in Gerber Accumark system. After sewing identifications are made to these patterns, virtual mannequin was worn as three dimensional in VStitcher program (Picture 7). 


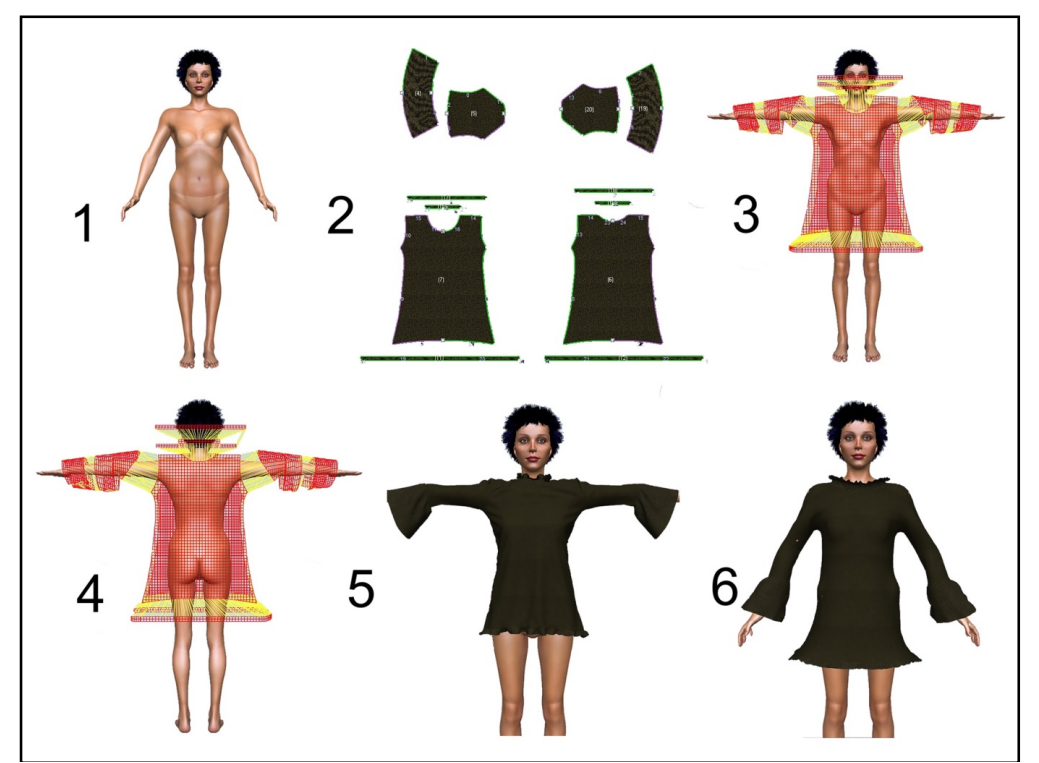

Picture 7. Virtual Mannequin's Dressing Stages In The V-Stitcher Program

\section{Obtaining The Research Data}

The compatibility of the virtual and actual try-on is evaluated by 20 field experts by comparing posture of the living mannequin from front, rear and sidewise in the real try-on and the screen shots of the virtual mannequin from the front, rear and sidewise in the virtual try-on. Likert type scale developed by the researchers was used for the evaluation. In the scale consisting of 2 sub-dimensions, body and arm compatibility, 14 criteria were determined for evaluating body compatibility and 5 criteria were determined in evaluating body compatibility. This criteria is related with the front, rear and sidewise posture. 5 likert which is very compatible, compatible, mean compatible, incompatible and very incompatible, is preferred in evaluating the criteria in the scale. The compatibility between the actual try-on and the virtual try-on is evaluated on the scale by being observed by the field experts.

\section{Analysis of The Data}

In the evaluation results which are expressed in five different levels in the scale, the compatibility points are calculated by giving 5 points for "very compatible", 4 points for "compatible", 3 points for "mean compatible", 2 points for "incompatible" and 1 point for" very incompatible". The evaluation is made with 20 experts' opinions therefore the maximum compatibility points is 100 for each criteria. The body consistency of 14 sub-dimensions and the maximum score that can be achieved for arm compliance consisting of 5 sub- dimensions are 1900. Five likert type scale is used while expressing the compatibility results according to the points, an evaluation is made by determining the 5 equal point intervals over the maximum points. The compatibility degrees are presented by calculating the percentages of the total points obtained over the maximum points for expressing the comparison results more apparently.

The point and percentage intervals of the virtual try-on showing the compatibility degree with the actual try on, are given in Table 1. 
Table 1. Evaluation of Compatibility

\begin{tabular}{|l|c|c|c|c|c|}
\hline \multicolumn{7}{|c|}{ POINT AND PERCENTAGE INTERVALS } \\
\hline $\begin{array}{l}\text { COMPATIBILITY/ } \\
\text { COMPATIBILITY } \\
\text { DEGREE }\end{array}$ & $\begin{array}{c}\text { Very } \\
\text { Compatible }\end{array}$ & Compatible & $\begin{array}{c}\text { Mean } \\
\text { Compatible }\end{array}$ & Incompatible & $\begin{array}{c}\text { Very } \\
\text { Incompatible }\end{array}$ \\
\hline $\begin{array}{l}\text { Point intervals of } \\
\text { each } \\
\text { evaluation criteria }\end{array}$ & $\begin{array}{c}81-100 \\
\text { point }\end{array}$ & $\begin{array}{c}61-80 \\
\text { point }\end{array}$ & $\begin{array}{c}41-60 \\
\text { point }\end{array}$ & $21-40$ point & $0-20$ point \\
\hline $\begin{array}{l}\text { Point intervals of } \\
\text { general } \\
\text { compatibility (Body } \\
\text { and arm) }\end{array}$ & $\begin{array}{c}152-1900 \\
\text { point }\end{array}$ & $\begin{array}{c}1141-1520 \\
\text { point }\end{array}$ & $\begin{array}{c}761-1140 \\
\text { point }\end{array}$ & $\begin{array}{c}381-760 \\
\text { point }\end{array}$ & $\begin{array}{c}0-380 \\
\text { point }\end{array}$ \\
\hline $\begin{array}{l}\text { Percentage intervals } \\
\text { of } \\
\text { general compatibility } \\
\text { (Body and arm) }\end{array}$ & $81-100 \%$ & $61-80 \%$ & $41-60 \%$ & $21-40 \%$ & $0-20 \%$ \\
\hline
\end{tabular}

\section{FINDINGS}

The try-on of a garment produced from knit fabric, is compared in virtual and actual environment. The compatibility between the virtual try-on results and the actual try-on results is evaluated by using five likert type scale. The evaluations are made in two stages as to be the evaluation of the compatibility of the body and arm.

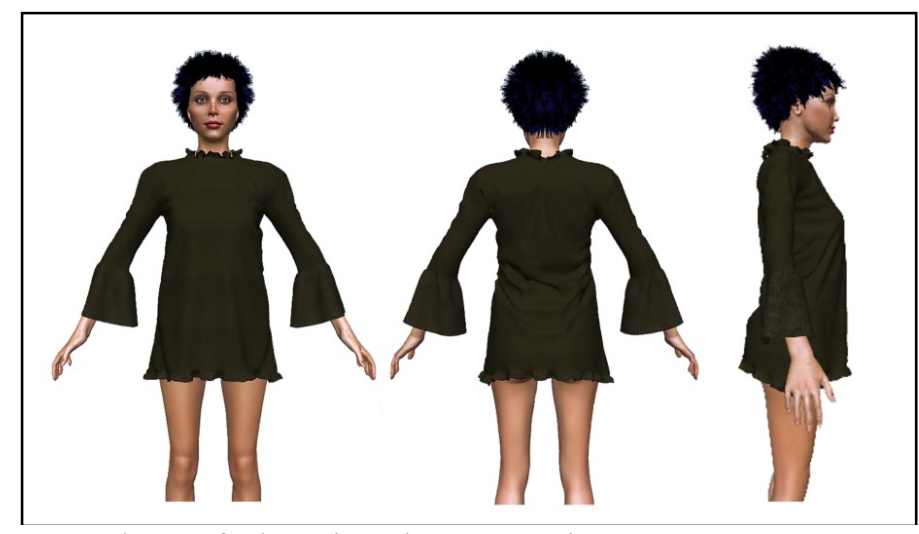

Picture 8. The Screen Shots of The Virtual Mannequin From Front, Rear and Sidewise For Body In Virtual Try On

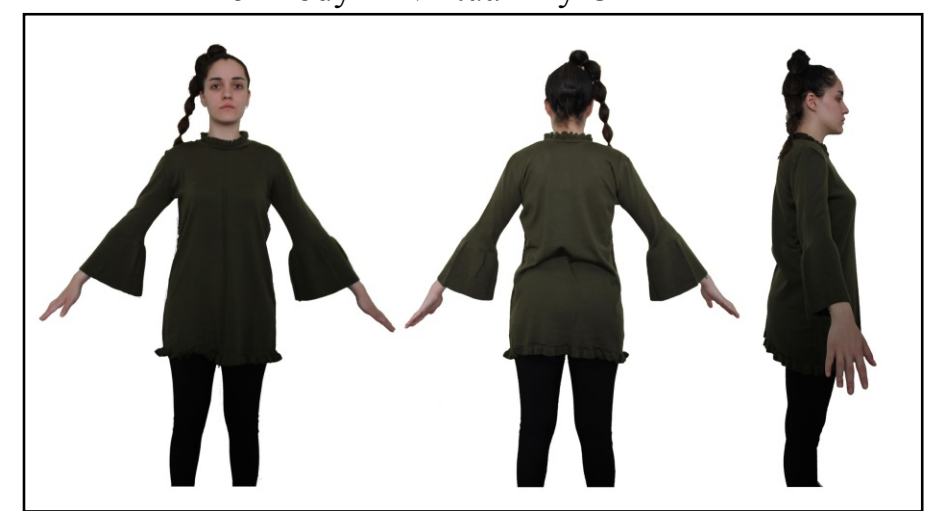

Picture 9. The Photos of The Living Mannequin From Front, Rear and Sidewise For Body In Real Try On 


\section{Findings Related With The Evaluation of The Body Compatibility}

In the analysis of the compatibility of the try-ons made in the virtual and actual environment, first the compatibility of the upper body is evaluated. The compatibility of the body is made in three stages as to evaluated body from front, body from rear, upper body and body from side. The screen shots of the virtual mannequin used in the evaluation of the compatibility of the body are given in picture 8 and the photos of the living model are given in picture 9.

Table 2. Evaluation of The Upper Body Compatibility

\begin{tabular}{|c|c|c|c|}
\hline \multicolumn{4}{|c|}{ EVALUATION OF THE BODY COMPATIBILITY } \\
\hline CRITERIAS OF EVALUATION & Point & $\begin{array}{l}\text { Compatibility } \\
\%\end{array}$ & $\begin{array}{l}\text { Compatibility } \\
\text { Degree }\end{array}$ \\
\hline \multicolumn{4}{|l|}{ A-Body from Front } \\
\hline 1- Front Neckline & 90 & 90 & Very Compatible \\
\hline 2-Necline on the Fluff & 74 & 74 & Compatible \\
\hline 3-View the tip of the Blouse & 80 & 80 & Compatible \\
\hline 4- Drape of the Fabric & 83 & 83 & Very Compatible \\
\hline 5- General View & 89 & 89 & Very Compatible \\
\hline $\begin{array}{l}\text { Total Compatibility of the Body from } \\
\text { Front }\end{array}$ & 416 & 83 & Very Compatible \\
\hline \multicolumn{4}{|l|}{ B- Body from Rear } \\
\hline 1- Rear neckline & 78 & 78 & Compatible \\
\hline 2- Necline on the Fluff & 71 & 71 & Compatible \\
\hline 3- View the tip of the Blouse & 87 & 87 & Very Compatible \\
\hline 4- Drape of the Fabric & 90 & 90 & Very Compatible \\
\hline 5- General View & 87 & 87 & Very Compatible \\
\hline $\begin{array}{l}\text { Total Compatibility of the Body from } \\
\text { Rear }\end{array}$ & 413 & 82 & Very Compatible \\
\hline \multicolumn{4}{|l|}{ C- Body from Side } \\
\hline 1- Appearance of godets & 80 & 80 & Compatible \\
\hline 2- Shoulder stitch view & 78 & 78 & Compatible \\
\hline 3- View the tip of the Blouse & 93 & 93 & Very Compatible \\
\hline 4- General View & 82 & 82 & Very Compatible \\
\hline $\begin{array}{l}\text { Total Compatibility of the Body from } \\
\text { Sidewise }\end{array}$ & 333 & 83 & Very Compatible \\
\hline $\begin{array}{l}\text { COMPATIBILITY DEGREE OF THE } \\
\text { BODY }\end{array}$ & 1162 & 83 & $\begin{array}{c}\text { VERY } \\
\text { COMPATIBLE }\end{array}$ \\
\hline
\end{tabular}

\section{Evaluation of Arm Compatibility}

In the analysis of the compatibility of the try-ons made in the virtual and actual environment, secondly the compatibility of the arm is evaluated. The data which is obtained as the result of the scoring the criteria used in evaluating the arm, is given in table 3 . When table 4 is evaluated, it is observed that general position of the arm has the highest compatibility percentage with \% 99 compatibility percentage and rear armhole of view has the lowest compatibility percentage with \% 86 compatibility percentage in the evaluation of arm. Generally, it is observed that the try-on results made in the virtual environment are very compatible with the try-on made in the actual environment and has the compatibility percentage of $\% 85$ in the compatibility of the arm. 
Table 3. Evaluation of Arm Compatibility

\begin{tabular}{|l|c|c|c|}
\hline \multicolumn{4}{|c|}{ EVALUATION OF ARM COMPATIBILITY } \\
\hline CRITERIAS OF EVALUATION & Point & $\begin{array}{c}\text { Compatibility } \\
\mathbf{\%}\end{array}$ & Compatibility Degree \\
\hline D-Arm from Front and Rear & 91 & 91 & Very Compatible \\
\hline 1- Front Armhole of View & 86 & 86 & Very Compatible \\
\hline 2- Rear Armhole of View & 99 & 99 & Very Compatible \\
\hline 3- Flywheel View & 96 & 96 & Very Compatible \\
\hline 4- Sleeve hem of View & 99 & 99 & Very Compatible \\
\hline 5- General Position of the Arm & $\mathbf{4 7 1}$ & $\mathbf{8 5}$ & VERY COMPATIBLE \\
\hline $\begin{array}{l}\text { COMPATIBILITY DEGREE OF } \\
\text { THE ARM }\end{array}$ & & & \\
\hline
\end{tabular}

\section{Evaluation of The General Compatibility}

The data related with the evaluation of the general compatibility between the virtual try-on and the actual try on is given in table 4 . When the general results are analyzed, it is observed that the try-on of the garment from the knit fabric is very compatible in virtual and actual environments. When the compatibility percentages of the body and arm are evaluated separately, the arm compatibility has the highest compatibility with the percentage of $\% 85$ and the body has the compatibility percentage of $\%$ 83 .

Table 4. Evaluation of The General Compatibility

\begin{tabular}{|l|c|c|c|}
\hline \multicolumn{4}{|c|}{ EVALUATION OF THE GENERAL COMPATIBILITY } \\
\hline $\begin{array}{l}\text { CRITERIAS OF } \\
\text { EVALUATION }\end{array}$ & Point & Compatibility \% & $\begin{array}{c}\text { Compatibility } \\
\text { Degree }\end{array}$ \\
\hline $\begin{array}{l}\text { 1-Compatibility of the upper } \\
\text { body }\end{array}$ & 1162 & 83 & Very Compatible \\
\hline 2-Compatibility of the arm & 471 & 85 & Very Compatible \\
\hline $\begin{array}{l}\text { GENEL UYUMLULUK } \\
\text { DERECESI }\end{array}$ & $\mathbf{1 6 3 3}$ & $\mathbf{8 5}$ & $\begin{array}{c}\text { VERY } \\
\text { COMPATIBLE }\end{array}$ \\
\hline
\end{tabular}

\section{CONCLUSION}

In this study, the virtual try-on results with the actual try-on result of a garment is evaluated by comparing the try-ons of a garment produced from the knit fabric in actual and virtual environments. It is observed that the try-on of the blouse produced from the knit fabric, made in virtual and actual environment is very compatible with each other. In the evaluation of the body and arm, the highest compatibility percentage belongs to the arm and the lowest compatibility percentage belongs to body. The reason why the compatibility percentages of the body are lower than the others, may be explained that the ruffle posture in the virtual provenance neckline, is not identified as a weight in the virtual tryon, it can be explained by the fact that the appearance of the virtual shoulder stitch is not very clear.

The virtual try-on was found as successful in terms of many criteria like gathering front neckline, drape of the fabric, view the tip of the blouse, flywheel view, sleeve hem of view expressing the posture of the knit fabric and it gave very compatible results with the try-on results on the actual mannequin. Therefore using 3 dimensional virtual try-on software, shall be more efficient in terms of time, effort and cost so it is though that the virtual try-on may be preferred instead of actual try-on.

\section{REFERENCES}

Ahlström, Pär \& Westbrook, Roy. (1999). "Implications of Mass Customization For Operations Management", International Journal of Operations and Production Management, 19 (3), s.262-274. https://doi.org/10.1108/01443579910249705.

Browzwear kullanım klavuzu, 2010. 
Bye, E. ve McKinney, E. (2010). "Fit analysis using live and 3D scan models". International Journal of Clothing Science and Technology, 22 (2/3), 88-100.

Gürsoy, F., Doğan, S. Kllınç, N., (2016). "Comparison Of The Try-Ons Of A Garment Produced From Rize Fabric (Feretiko) In Actual And Virtual Environments". $7^{\text {th }}$ International Istanbul Textile Conference, Anadolu'ya Doku "N" an Bezler, BEZCE 2016, 869-878.

Fan, J., Yu W. ve Hunter, L. (2004). "Clothing appearance and fit: Science and technology". Cambridge: Woodhead Publishing Limited and CRC press LLC.

Iqbal, Muhammad. (2013). Virtual Product Development and Management Opportunities in Fashion Industry, Master of Science Thesis, Tampere University of Technology.

Istook, Cynthia, (2008), Three Dimensional Body Scanning to Improve Fit, Advances in Apparel Production, England: Woodhead Publishing Ltd. Cambridge. doi: 10.1533/9781845694463.1.94

Tama, D., Şen Kılıç, A., Öndoğan, Z., Nizamoğlu, S., (2016). "Vücudu Saran Giysilerin Tasarımında ve Giysi Kalıbı Hazırlı̆̆ında 3 Boyutlu Açınım Sistemlerinin Kullanılabilirliği". Çukurova Üniversitesi Mühendislik-Mimarlık Fakültesi Dergisi, 31 (ÖS2), s.169-174.

Vuruşkan, Arzu \& Bulgun, Ender. (2013). "Fit Analysis for Made-to-Measure Garments", Tekstil ve Mühendis, 20 (90), s.42-53. http://dx.doi.org/10.7216/130075992013209005.

Yeşilpınar, S. ve Bulgun, E., (2007). "Garment fitting problems of Turkish females towards mass customization". Proceedings of Autex, 2007, Tampere University of Technology, Finland. 